Annu. Rev. Microbiol. 2021. 75:X-X

https://doi.org/10.1146/annurev-micro-032921-123231

Copyright @ 2021 by Annual Reviews.

All rights reserved

Li et al.

www.annualreviews.org $\bullet$ Predation Using Metals

\title{
Antimicrobial Activity of Metals and Metalloids
}

Yuan Ping Li, ${ }^{1}$ Ibtissem Ben Fekih, ${ }^{1}$ Ernest Chi Fru, ${ }^{2}$ Aurelio Moraleda-Munoz, ${ }^{3}$

Xuanji Li, ${ }^{4}$ Barry P. Rosen, ${ }^{5}$ Masafumi Yoshinaga, ${ }^{5}$ and Christopher Rensing ${ }^{1}$

${ }^{1}$ Institute of Environmental Microbiology, College of Resources and Environment, Fujian Agriculture and Forestry University, Fuzhou 35002, China; email: rensing @iue.ac.cn

${ }^{2}$ Centre for Geobiology and Geochemistry, School of Earth and Ocean Sciences, Cardiff University, CF10 3AT Cardiff, United Kingdom

${ }^{3}$ Departamento de Microbiología, Facultad de Ciencias, Universidad de Granada, Granada 18071, Spain

${ }^{4}$ Department of Biology, University of Copenhagen, DK-2200 Copenhagen, Denmark

${ }^{5}$ Department of Cellular Biology and Pharmacology, Herbert Wertheim College of Medicine, Florida International University, Miami, Florida 33199, USA

\section{Keywords}

copper, methylated arsenicals, predation, poisoning, arsinothricin

\begin{abstract}
Competition shapes evolution. Toxic metals and metalloids have exerted selective pressure on life since the rise of the first organisms on the Earth, which has led to the evolution and acquisition of resistance mechanisms against them, as well as mechanisms to weaponize them. Microorganisms exploit antimicrobial metals and metalloids to gain competitive advantage over other members of microbial communities. This exerts a strong selective pressure that drives evolution of resistance.
\end{abstract}


This review describes, with a focus on arsenic and copper, how microorganisms exploit metals and metalloids for predation and how metal- and metalloid-dependent predation may have been a driving force for evolution of microbial resistance against metals and metalloids.

\section{INTRODUCTION}

Competition has been an integral part of the evolution of life. It is difficult to identify the beginning of life, but it is clear that archaea, bacteria, and bacteriophages were the earliest life-forms to emerge on the primordial Earth (35). Archaea and bacteria have always waged war with each other, competing for limited resources (53).

Predator-prey relationships accelerated the rate of evolution and transition to more complex and larger life-forms by $650 \mathrm{Ma}$ (107). Reciprocal selection altered the biotic selective environment of both predator and prey (112). These predator-prey interactive networks are proposed to have accelerated the pace of evolution. In this evolutionary arms race, superior weapons such as metals and metalloids are essential for the predator, whereas superior defenses are essential for the prey. In this review, we focus primarily on copper and arsenic. In terms of evolution, once a predator species attacks a prey species, survivors must develop ways to defend themselves, such as active efflux. Prey resistance, in turn, forces the predator to acquire new weapons - for example, other toxic metals or antimicrobial peptides-leading to a new cycle of selective prey resistance. Therefore, predator and prey evolve in parallel to avoid extinction. The hypothesis termed Red Queen coevolution (106) refers to the Red Queen in Alice's Adventures in Wonderland, who explained the land in the looking glass: "Now, here, you see, it takes all the running you can do, to keep in the same place."

Life has been exposed to the toxic metalloid arsenic (Figure 1) and the toxic metal copper (Figure 2) since the rise of the first organisms, approximately 3.5 Ga, during the Archean eon (4$2.5 \mathrm{Ga})(27,31,32,165)$. The first bacteria not only adapted to survive in the presence of arsenic but also adapted the toxic metalloid as an offensive weapon in microbial warfare to gain a competitive advantage (23). Many organisms, from bacteria to vertebrates, have genes for 
conversion of arsenic into weapons and/or genes that protect them from arsenic toxicity. In bacteria, these genes are nearly all found in arsenic resistance (ars) operons. Here, we briefly examine copper availability through the Earth's history and the factors that controlled its bioavailability, given that the evolution of life as a whole has always been linked to the bioavailability of essential metals $(34,93,127)$.

\section{<COMP: PLEASE INSERT FIGURE 1 AND 2 HERE>}

Figure 1 Geological time line for marine arsenic evolution and the emergence of genes encoding proteins with functions responsible for arsenite methylation [arsM, encoding As(III) $S$ adenosylmethionine methyltransferase] and MAs(III) resistance [arsI, encoding MAs(III) demethylase, and arsH, encoding MAs(III) oxidase] and for the As(III) efflux permease (acr3), and corresponding atmospheric oxygen trends. (a) Emerging model for atmospheric oxygenation (88, Large et al. (2020)). The question mark represents a proposed 1.4-Gy oxygenation event suggested by Diamond and Lyons (44a; see also Large, 2019). (b) Arsenic concentrations in marine iron formations and shales (see 28). (c) Arsenic concentrations in marine sediments normalized to the strong arsenic sink iron. The red lines in panels $b$ and $c$ represent the moving averages. Abbreviations: As(III), arsenite; GOE, Great Oxidation Event; MAs(III), methylarsenite; NOE, Neoproterozoic Oxygenation Event; PAL, present-day atmospheric level; $\mathrm{PO}_{2}$, partial pressure of oxygen.

Figure 2 Geological time line for marine copper evolution and corresponding atmospheric oxygen trends. (a) Emerging models for atmospheric oxygenation (see 88, Large et al. (2020)). (b) Copper concentrations in marine iron formations. (c) Copper concentrations in marine shales. The red lines in panels $b$ and $c$ represent the moving averages. Abbreviations: GOE, Great Oxidation Event; NOE, Neoproterozoic Oxygenation Event; PAL, present-day atmospheric level; $\mathrm{PO}_{2}$, partial pressure of oxygen. Panels $b$ and $c$ adapted from Reference 31.

\section{ARSENIC DYNAMICS THROUGHOUT THE EARTH'S HISTORY}

During the anoxic Archean eon, geochemically derived inorganic arsenic would have existed primarily as trivalent arsenite [As(III)]. About $2.4 \mathrm{Ga}$, the Earth's atmosphere and ocean surface became permanently oxygenated, during the Great Oxygenation Event (GOE) (Figure 1a), which oxidized inorganic arsenic (88). Historical records of marine arsenic sedimentary dynamics reconstructed from marine sedimentary iron formations and shales suggest that early oceans were rich in arsenic. However, the dissolved concentrations would have been modulated by the high 
iron content, which would have acted as a potent sink for arsenic removal from seawater (Figure 1b). Iron formations occurred predominantly 4.0-1.8 Ga and then reappeared briefly toward the end of the Proterozoic eon $(0.5 \mathrm{Ga})$ in association with the termination of the Neoproterozoic global glaciations that occurred 0.720-0.635 Ga. This Neoproterozoic oxygenation event (NOE) rise of marine arsenic content coincided with the NOE that followed the glaciations (Figure 1ac). These glaciations and the earlier Huronian snowball Earth glaciation, which coincided with the GOE 2.4-2.1 Gy (88), severely curtailed release of arsenic into oceans because of icehousesuppressed weathering coupled to an inefficient hydrological cycle (28).

Concentrations of arsenic in marine sedimentary iron formations and shales suggest a high Archean arsenic concentration with four critical peaks and three key depressions through Earth's history (Figure 1b). The high Archean arsnic concentrations declined dramatically following the onset of the GOE and the associated Huronian snowball Earth glaciation (Figure 1b). Following deglaciation and return to a greenhouse state, the arsenic concentrations increased again (31). A major arsenic spike occurred $1.4 \mathrm{Ga}$, when atmospheric oxygen briefly rose (82). Another spike occurred during the Marinoan snowball Earth glaciation, which ended $635 \mathrm{Ma}$. The post-snowball Earth glaciation increases have been linked to increased concentrations of arsenic coming from continental bedrock erosion due to the deglaciating ice sheets that delivered soluble arsenic to the oceans (31).

The highest extant arsenic concentrations are found in shallow marine iron formations from the hydrothermal vent fields of Milos Island, Greece, where hydrothermal fluids contain greater than 3,000-fold more arsenic than seawater $(9,30)$. At this site, the arsenic efflux gene, acr3 (27), is the most abundant arsenic-detoxifying gene found in microbial communities $(12,32)$. These modern shallow marine hydrothermal ecosystems are differentiated into iron oxide, sulfidic, anoxic, and oxic ecosystems similar to those that predominated the Precambrian world $(29,119)$. Genes such as ars3 are also widespread in the volcanic arsenic-rich ecosystems of the Andes Mountains, which are believed to be similar to the earliest oceans $(123,133)$. 
Early marine arsenic concentrations would have been modulated by the large volume of ironrich precipitates that became vast iron formations (Figure 1c). Nonetheless, a similar series of events was replicated when arsenic was normalized to iron concentrations (Figure 1c), as well as without normalization (Figure 1b). This implies that As(III) was the dominant inorganic arsenic species in the geobiosphere prior to $2.4 \mathrm{Ga}$ because of its stability and high mobility in anoxic conditions. Pentavalent arsenate $[\mathrm{As}(\mathrm{V})]$ and various arsenic sulfides became the prominent species following the $\operatorname{GOE}(28,32)$. The resultant shift in the oxidation state of arsenic is thought to have triggered new adaptive responses in existing microbial communities $(27,32)$.

\section{COPPER THROUGHOUT THE EARTH'S HISTORY}

A detailed examination of marine iron formations and shales suggests that long-term variations in sedimentary marine copper concentrations in the geological record were generally small (Figure 2). The data, however, reveal significantly more copper burial in association with iron oxide-rich iron formations relative to iron oxide-poor marine shales that are predominantly a product of continental weathering (Figure $2 \boldsymbol{b}$ ). These observations insinuate that the reactive marine iron reservoir has controlled dissolved seawater copper concentrations throughout the Earth's history (31). Similar to the case of arsenic bioavailability, iron-rich ecosystems such as those that prevailed in the early oceans served as major sinks for dissolved copper, and recent evidence further points to seawater sulfide and organic matter content as powerful copper sinks (34).

Thus, redox cycling of iron, sulfur, and carbon would have played a major role in copper bioavailability, especially after the GOE and the NOE. For example, there was a progressive reduction in seawater iron concentration across the Archean-Proterozoic boundary until about 0.58 $\mathrm{Ga}$, when the deep oceans first became fully oxygenated (119). This gradual reduction in the size of the ocean iron reservoir after the GOE would have promoted an increase in dissolved surficial seawater copper concentrations. These conditions would have enabled life on the iron-poor, open, oxygenated ocean surface to flourish in greater dissolved copper conditions. On the other hand, sulfide-related copper scavenging in the mid-depth near continental margin habitats where sulfide 
was prevalent and by the iron oxides that accumulated in the iron-rich deep ocean (119) would have promoted low copper bioavailability in these habitats. By allowing greater copper bioavailability in the iron-deficient, sulfide-poor, oxygen-rich surfaces of oceans, this would have conferred a selective advantage for biological copper utilization, including the potential for the development of copper-containing biological weapons.

\section{ARSENIC-DEPENDENT BIOLOGICAL WARFARE}

One of the first enzymes in arsenic biotransformation to have evolved was ArsM, bacterial As(III) $S$-adenosylmethionine methyltransferase, which can be traced back to nearly 3.5 Ga by molecular clock reconstruction (27) (Figure 1a). ArsM methylates inorganic As(III) into highly toxic methylarsenite [(MAs(III)] and dimethylarsenite [DMAs(III)] and nontoxic volatile trimethylarsine [TMAs(III)] gas (Figure 3a). Only later did Acr3 and ArsP, the efflux permeases, evolve (Figure 1a) to confer resistance to As(III) and MAs(III), respectively (Figure 3a). While it may seem paradoxical that microbes would first make arsenic more toxic before coming up with ways to tolerate it, one must consider that even the first microorganisms would have been under selective pressure to outgrow each other; this was the origin of microbial warfare. Bacteria that innovated the ability to methylate inorganic arsenic turned this unique adaptation into a potent weapon, a powerful selective and competitive advantage against competitors.

\section{<COMP: PLEASE INSERT FIGURE 3 HERE>}

Figure 3 Bacterial warfare over arsenic: mechanisms of $(a-c)$ production, $(d)$ action, and $(e)$ resistance of organoarsenical antimicrobials. (a) MAs(III) production via methylation. As(III), which enters bacterial cells via aquaglyceroporins such as GlpF, is extruded via As(III) efflux permeases such as Acr3 (Mechanism 1). Some bacteria methylate As(III) by ArsM, producing MAs(III), which has potent antimicrobial properties (Mechanism 2). MAs(III) is secreted via selective efflux permeases (ArsP, ArsK) or potentially via channels such as GlpF or unknown pathways (Mechanism 3). Some of the produced MAs(III) is further methylated by ArsM to dimethylated DMAs(III) (Mechanism 4), which may also function as an antibiotic. Additional methylation produces nontoxic, volatile, gas - trimethylated TMAs(III) (Mechanism 5), which probably confers self-resistance against MAs(III)/DMAs(III), especially in anaerobic conditions. In aerobic conditions, MAs(III), DMAs(III), and TMAs(III) are rapidly oxidized to nontoxic pentavalent counterparts in air (Mechanism 6). (b) MAs(III) production via reduction. Some 
aerobes acquired the ability to reduce nontoxic MAs(V) to MAs(III) (Mechanism 1), utilizing it as an antibiotic. Some MAs(V)-reducing aerobes are also capable of reduction of aromatic arsenate to produce aromatic arsenite (Mechanism 2) and have potent antimicrobial activity. Molecular mechanisms for the organoarsenical reduction are yet unknown. (c) AST production. Some bacteria have even evolved to biosynthesize a more complex organoarsenical antibiotic. The pathways for AST biosynthesis and efflux are yet unknown. (d) Mechanisms of action. MAs(III) and aromatic As(III) taken up by neighboring cells, probably via GlpF, inhibit various proteins involved in bacterial-life-supporting processes such as peptidoglycan biosynthesis (Mechanism 1) and the TCA cycle (Mechanism 2) by binding their cysteine residues. MAs(III) and aromatic As(III) also bind to and deplete small proteins and other small molecules for regulation of redox homeostasis such as glutaredoxin/thioredoxin (Mechanism 3) and GSH (Mechanism 4), leading to damage from ROS. AST, taken up by surrounding cells via unknown pathways, inhibits GlnS (Mechanism 5), causing accumulation of toxic ammonia and depletion of glutamine, which lead to bacterial death. (e) Resistance mechanisms. Some bacteria have evolved resistance mechanisms against organoarsenical antibiotics for survival. ArsP and ArsK are specific efflux permeases that extrude MAs(III) and aromatic As(III) out of the cells, which confers resistance in an oxygenindependent manner (Mechanism 1). In contrast, ArsI (Mechanism 2) and ArsH (Mechanism 3) detoxify MAs(III) and aromatic As(III) in an oxygen-dependent manner: ArsI is a dioxygenase that degrades them into As(III) by incorporating a dioxygen molecule into the carbon-arsenic bond; ArsH is an oxidase that oxidizes them to nontoxic pentavalent counterparts. Some anaerobes have a resistance mechanism specific for aromatic As(III) but not for MAs(III), which completes the detoxification process by ArsG, the aminoaromatic-As(III)-specific efflux permease (Mechanism 4). ArsN1 (Mechanism 5) is the only known AST-resistant mechanism and detoxifies AST by acetylation. Abbreviations: AcAST, $N$-acetyl arsinothricin; AcCoA, acetyl coenzyme A; Acr3, As(III) efflux permease; ArsG, aminoaromatic arsenite efflux permease; ArsH, methylarsenite oxidase; ArsI, methylarsenite demethylase; ArsK, arsenite/methylarsenite efflux permease; ArsM, arsenite $S$-adenosylmethionine methyltransferase; ArsN1, arsinothricin $N$ acetyltransferase; ArsP, methylarsenite efflux permease; As(III), arsenite; As(V), pentavalent arsenate; AST, arsinothricin; DMAs(III), dimethylarsenite; DMAs(V), dimethylarsenate; GlnS, glutamine synthetase; GlpF, aquaglyceroporin; Grx, glutaredoxin; GSH, reduced glutathione; GS, glutathionyl group; MAs(III), methylarsenite; MAs(V), methylarsenate; ROS, reactive oxygen species; SG, glutathionyl group; TCA, tricarboxylic acid; TMAs(III), trimethylarsine; TMAs(V)O, trimethylarsine oxide; Trx, thioredoxin.

In support of this novel hypothesis, in extant soil microbial communities, biogenic MAs(III) exhibits antimicrobial properties (23). MAs(III) fits the classical definition of antibiotic introduced by Selman Waksman in the 1940s: a toxic organic compound produced by one microbe to kill competitors (152). DMAs(III) may also have antibiotic-like properties, but its lower stability compared with MAs(III) reduces its effectiveness as an antibiotic. Further methylation generates 
nontoxic volatile TMAs(III) gas, which may have functioned as a primitive self-protection mechanism in the producing microbe against the MAs(III) and DMAs(III) that it generates (Figure $3 a)$, especially before the evolution of more sophisticated and effective mechanisms such as ArsP. MAs(III) is very reactive and may have multiple targets in bacteria. Recently one bacterial target of trivalent organoarsenicals was identified (51a). MAs(III), but not inorganic As(III), effectively inhibits MurA, the bacterial enzyme involved in the first step of peptidoglycan synthesis, suggesting that one mechanism of action of trivalent organoarsenical antimicrobials is inhibition of bacterial cell wall synthesis (Figure $3 \boldsymbol{d}$ ).

The ars $M$ gene is widespread, mainly in the Bacteria domain, where it is thought to have first emerged. However, as a result of lateral gene transfer, the ars $M$ gene has been acquired by archaea and eukaryotes, including algae, fungi and protists as well as by various animal lineages; the human gene is $A S 3 M T(26)$.

The widespread distribution of the $\operatorname{ars} M$ gene raises the question of why methylated arsenicals are not abundant in the natural environment. For example, it is puzzling that most of the arsenic present in seawater is not methylated and sequestered in marine biomass. Methylated arsenicals are the likely precursors of more complex organoarsenicals, such as arsenosugars (156), arsenolipids, arsenobetaine, and related compounds, that are sequestered by cyanobacteria and algae, resulting in bioaccumulation and biomagnification up the food chain. Since these complex organoarsenicals are nontoxic, they likely represent an arsenic detoxification mechanism (144). These organoarsenicals are not easily biodegraded. For example, marine DMAs(V) has an 8.1-day turnover rate (56). So the biomass of dead marine organisms is an arsenic sink in marine sediments.

In general, antibiotic producers are resistant to the antibiotics that they produce; for example, efflux pumps remove antibiotics from the cell (103). Acr3 and ArsP are efflux permeases for As(III) and MAs(III) (23) (Figure 3a), respectively. The molecular fossil record is not entirely clear, but the ars $P$ gene appears to have evolved more recently than ars $M$ and acr3 and spread through prokaryotes by horizontal gene transfer as a mechanism for MAs(III) resistance (27). However, the times of origin of ars $M$ and ars $P$ overlap to some degree, so another possibility is 
that ArsP evolved in parallel with ArsM to provide the producer with another way to become resistant to its own product. Another pathway for MAs(III) efflux is via bacterial aquaglyceroporin channels such as GlpF (51) (Figure 3a). GlpF facilitates As(III) uptake in Escherichia coli (134), and the human liver ortholog AQP9 is a bidirectional facilitator of both As(III) and MAs(III) (51). These channels move As(III) into cells and down the As(III) concentration gradient from higher extracellular to lower intracellular levels. If As(III) is methylated inside of bacterial cells, the generated MAs(III) could flow down its concentration gradient into the extracellular milieu. In effect, therefore, bacterial GlpF orthologs exchange extracellular As(III) for intracellular MAs(III), providing a pathway for protecting MAs(III) producers from the bactericidal activity of MAs(III). This speculation implies an early origin for the bacterial aquaglyceroporin gene. However, these aquaglyceroporins are generalized channels for metalloids, including not only toxic arsenic and antimony, but also boron and silicon, which have structural roles in plants (98) and might have had similar physiological functions in the first organisms. The major facilitator superfamily also has members that transport MAs(III), such as ArsK (140) (Figure 3a). ArsK has lower selectivity than ArsP and confers resistance to not only MAs(III) but also inorganic As(III). When the arsK gene emerged is unclear due to lack of molecular clock analyses.

As discussed above, MAs(III) may have been a primordial antibiotic. Some members of present-day microbial communities produce MAs(III), but this is subsequently detoxified abiotically by oxidation in air to MAs(V) (Figure 3a). However, members of aerobic microbial communities reduce $\mathrm{MAs}(\mathrm{V})$ by yet unidentified pathways (160), taking advantage of the availability of microbially generated MAs(V) (Figure $3 \boldsymbol{b}$ ) and producing a competitive advantage over arsenic-sensitive community members. Since this cycle of methylation, oxidation, reduction, and resistance involves a number of bacterial species, these complex interactions are emergent properties of the entire microbial community (23). A hallmark of the battles that take place in microbial jungles is that when one species produces an antibiotic, others acquire resistance mechanisms, as is the case for toxic biogenic MAs(III) (Figure 3e). Some sensitive bacteria acquired oxygen-independent resistance genes such as $\operatorname{ars} P$ by horizontal gene transfer (Figure 
3e), rendering them resistant to MAs(III). After the GOE, there were new opportunities for evolution of resistance mechanisms. First, microbial methylation of As(III) to MAs(III) by ArsM became a detoxification mechanism as MAs(III) was oxidized to MAs(V) in air (Figure $3 a$ ). Second, the permanence of oxygen in the atmosphere provided selective pressure for the evolution of new pathways of resistance using oxidative reactions (158). Two oxygen-utilizing enzymes have been identified: ArsI and ArsH. ArsI is an MAs(III) demethylase, or a carbon-arsenic bond lyase that confers resistance to MAs(III) by cleaving the bond between the carbon and arsenic atoms and forming less toxic As(III) (161) (Figure 3e). ArsH is an MAs(III) oxidase that catalyzes oxidation of MAs(III) to MAs(V), thus detoxifying it (21) (Figure 3e). There are a few known MAs(V) reducers (23), all of which carry the arsH gene in their own ars operon, presumably for self-protection from the generated MAs(III). The MAs(III) resistance genes (ars $P$, arsK, arsI, and arsH) are widely distributed in bacteria, which in turn supports our hypothesis that bacteria generating MAs(III), by either inorganic arsenic methylation or MAs(V) reduction, utilize it for predation.

\section{AROMATIC ARSENICALS}

Since Antoine Béchamp's synthesis of the first artificial aromatic arsenical, atoxyl [also called $p$ arsanilic acid, p-aminophenylarsenate, or p-ASA(V)], in 1859 (78), a number of aromatic arsenicals have been synthesized and utilized in medicine (55), farming (90), and the military (122). Many bacteria tolerate or metabolize synthetic organoarsenicals, showing their ability to rapidly adapt to new environmental stresses.

Arsenic is one of the oldest medicines, used in ancient Greece, Rome, and China (78). Salvarsan, the first chemotherapeutic drug, is an aromatic arsenical (154). This magic bullet, the first effective antisyphilis drug, was developed by Paul Ehrlich in 1910 and was based on atoxyl. Salvarsan soon became the most prescribed drug worldwide and made significant contributions to the improvement of public health until the advent of penicillin, in the 1940s. Synthetic aromatic arsenicals were next applied to animal husbandry. For decades, they have been used mainly as 
antiprotozoals to promote growth of poultry and swine (90). Four pentavalent aromatic arsenicals-roxarsone [4-hydroxy-3-nitrophenylarsenate, or $\operatorname{Rox}(\mathrm{V})], \quad$ nitarsone $[p$ nitrophenylarsenate, or Nit(V)], p-ASA, and carbarsone [ 4-carbamoylaminophenylarsenate, or Car(V)] - were registered in the mid-1940s and used extensively in the United States until they were banned in mid-2010 because they led to higher arsenic concentrations in poultry meat; however, they are still used in other countries. Those aromatic arsenicals are not highly accumulated in animals; the majority of the drugs is excreted unchanged. Although they are modified by methylation, acetylation, and other reactions, it is not clear whether those modifications take place in the animals (by themselves, their microbiomes, or both) or in the excreted litter (159). Animal manure used as fertilizer has introduced massive amounts of aromatic arsenicals into the environment over the last decades. It is estimated that nearly 900 tons of the most widely used compound, roxarsone, was released into the environment in 2000 by the poultry industry in the United States (129). As is true for inorganic and methylated arsenicals, aromatic arsenicals are more toxic in reduced trivalent forms compared with their oxidized pentavalent counterparts (51). As described below in this section, soil bacteria have genes for roxarsone degradation $(22,24,157)$, so roxarsone in animal manure is eventually recycled.

Paul Ehrlich predicted that "drug resistance follows the drug like a faithful shadow" (as quoted in Reference 48a, p. 141), and resistance to salvarsan emerged in the 1930s. It was reasonable to predict that massive use of roxarsone and other aromatic arsenicals would promote bacterial adaptation. Notably, the nitrogen-fixing legume symbiont Sinorhizobium meliloti 1021 activates $\operatorname{Rox}(\mathrm{V})$ by transforming it into trivalent 4-hydroxy-3-aminophenylarsite [HAPA(III)] via two sequential steps: (a) reduction of the nitro group to an amine by the NADPH-dependent nitroreductase $\mathrm{MdaB}$ and $(b)$ reduction of the pentavalent arsenic atom to trivalence by an unknown mechanism (157) (Figure 3b). S. meliloti is also capable of reducing pentavalent p-ASA to the bioactive form $p$-ASA(III), and it also reduces MAs(V) to MAs(III) (Figure $3 \boldsymbol{b}$ ). Pseudomonas putida can also reduce the nitro group of roxarsone by using the chromosomally encoded $n f n B$ gene product, another FMN-NADPH-dependent nitroreductase (22). NfnB is not 
organoarsenical specific, and the gene is not in ars operons, but this nitroreduction confers resistance to trivalent roxarsone [Rox(III)]. However, among known MAs(V) reducers, only $S$. meliloti is capable of reducing both the nitro group and the arsenic atom of aromatic arsenicals, presumably utilizing them as antimicrobials (Figure $\mathbf{3 b}$ ). Utilization of aromatic arsenicals as antimicrobials could provide the producers a major advantage over competitors in microenvironments. The MAs(III)-resistance genes $\operatorname{ars} P$, arsI, ars $H$, and $\operatorname{ars} K$ also confer resistance to trivalent aromatic arsenicals (Figure 3e). Notably, a novel arsEFG operon confers specific resistance to aromatic arsenicals and has been recently identified in a number of obligate and facultative anaerobes (24). ArsE and ArsF reduce the nitro group of Rox(III) or trivalent nitarsone $[\mathrm{Nit}(\mathrm{III})]$ to an amino group, generating $\mathrm{HAPA}(\mathrm{III})$ or $p$-aminophenylarsenite $[p$ ASA(III)]. ArsG extrudes those trivalent aromatic aminoarsenicals out of the cells, completing the resistance pathway (Figure 3e). A unique feature of ArsEFG is that it confers resistance to aromatic arsenicals but not MAs(III).

\section{ARSINOTHRICIN}

Recently Burkholderia gladioli GSRB05, a bacterial isolate from the rhizosphere of rice grown in an arsenic-contaminated site, was demonstrated to synthesize two novel organoarsenical compounds from inorganic arsenite As(III) (79) (Figure 3c). The two new organoarsenicals are 2amino-4-(hydroxymethylarsinoyl) butanoate, named arsinothricin (AST), and 2-amino-4(dihydroxyarsonoyl) butanoate, termed hydroxyarsinothricin (AST-OH). These names were chosen due to the structural similarity of the compounds with phosphinothricin (PT), which is the Streptomyces-produced phosphonate antibiotic, and the unmethylated species demethyl PT (DMPT), an intermediate in the biosynthesis of PT. The mechanism of action of PT is competitive inhibition of bacterial glutamine synthetase (GS) that results in accumulation of toxic ammonia and lack of glutamine and leads to bacterial killing (105) (Figure 3d). The inhibitory activity of AST against bacterial GS is similar to PT activity against bacterial GS, but the antimicrobial activity of AST against several different bacteria is 15-fold greater than that of PT (105). This may 
be due to higher permeability of AST. AST effectively inhibits growth of both gram-positive and gram-negative bacteria, including pathogens such as Mycobacterium bovis BCG, which is the etiological agent of bovine tuberculosis, and carbapenem-resistant Enterobacter cloacae, which the World Health Organization has designated a critical priority pathogen. Thus, AST is a potent broad-spectrum antibiotic (105). When B. gladioli was cultured with As(III), the amount of AST$\mathrm{OH}$ increased and then gradually decreased and AST reciprocally increased. This suggests that AST-OH is the precursor of AST, just as DMPT is the precursor of PT (79).

AST is another example of arsenic used by bacteria as an antibiotic. As mentioned, pentavalent arsenic species are much less toxic than trivalent species. The abovementioned methylated and aromatic arsenite antimicrobials are in reduced trivalent form, and their potent antimicrobial effect is due to their robust affinity with thiols in $(a)$ enzymes that are essential for carbohydrate metabolism such as pyruvate dehydrogenase and $\alpha$-ketoglutarate dehydrogenase (148) (Figure 3d) and $(b)$ redox-regulating small proteins and small molecules such as glutaredoxin, thioredoxin, and glutathione (Figure 3d). Thus, the range of their target molecules is rather broad (139). In contrast, AST contains pentavalent arsenic and is as toxic as trivalent MAs(III) because it has a different mechanism of action than trivalent arsenicals (105). Because it is a pentavalent arsenical, this arsenic-based antibiotic likely emerged after the GOE.

Bacterial resistance against AST is conferred by $N$-acetylation of the $\alpha$-amino group catalyzed by ArsN1 (105), an enzyme belonging to the GCN5-related $N$-acetyltransferases (GNATs) superfamily (11). PpArsN1, encoded in the ars operon of $P$. putida KT2440, is an AST-selective $N$-acetyltransferase.

Phosphonate natural products, represented by PT, are a rich source of antibiotics (66). AST is the arsonate counterpart of PT, and we predict that additional arsonate antibiotics exist. arsN2, a gene encoding a second type of GNAT, is found in bacterial ars operons $(105,138)$. ArsN2 is distinct from ArsN1 and more closely related to $N$-acetylglutamate synthetase (ArgA), which catalyzes $\mathrm{N}$-acetylation of glutamate, the initial step in de novo arginine biosynthesis (20). No 
function has been identified for ArsN2, but we propose that it confers resistance against another yet unknown arsenic-containing antibiotic.

\section{COPPER HOMEOSTASIS: THE NEED FOR A BALANCE}

Copper is an essential trace transition metal in most organisms $(52,80)$. More than two-thirds of all species depend on this metal (126). However, excess copper is toxic because of several mechanisms, including generation of reactive oxygen species, displacement of iron from ironsulfur clusters, thiol depletion in the glutathione pool, and mismetallation and inactivation of metalloproteins due to replacement of other metal cofactors (Figure $4 \boldsymbol{b}$ ). Consequently, all organisms have developed methods to respond to low and high copper levels. These mechanisms involve (a) active efflux by $\mathrm{P}_{1 \mathrm{~B}}$-type ATPases, the RND (resistance-nodulation-cell division)-type transport systems, and cation diffusion facilitators $(2,43,95,96,108)$ (Figure $4 \boldsymbol{b}$ ); (b) cellular sequestration by metallochaperones (128) (Figure $4 \boldsymbol{b}$ ); and (c) oxidation of $\mathrm{Cu}(\mathrm{I})$ to less toxic $\mathrm{Cu}(\mathrm{II})$ by multicopper oxidases $(17,130)$. Intracellular copper is controlled by metal-sensing regulatory transcription factors and signaling systems including one-component systems, twocomponent systems, serine-threonine protein kinases, and extracytoplasmic-function sigma factors $(87,94,121)$. Although many organisms possess copper exporters that can protect them against copper uptake, there is little correlation between occurrence of copper transporters and cuproproteins, suggesting that pathways of utilization and detoxification evolved independently (126).

\section{<COMP: PLEASE INSERT FIGURE 4 HERE>}

Figure 4 Copper involvement in bacterial interactions. (a) Prey differentiation to hamper copper toxicity. (b) Mechanisms of copper toxicity and defensive prey responses. (Mechanism 1) Copper may be pumped out by predator active efflux systems, generating a gradient of increasing metal concentration toward the predator-prey interface. (Mechanism 2) Copper can also be dispatched from the predator via outer membrane vesicles. (Mechanism 3) Complexation of predator antibiotics with copper can result in a synergistic increase in the antimicrobial capability of both compounds. On the contrary, (Mechanism 4) interaction of copper with prey antibiotics can inactivate the antibiotic or reduce its activity. (Mechanism 5) $\mathrm{Cu}$ (II) sequestration by metallophores protects from catecholate-mediated toxic $\mathrm{Cu}(\mathrm{I})$ formation. Once copper reaches the 
reducing bacterial cytoplasm, the metal can exert toxicity through different processes: (Mechanism 6) $\mathrm{Cu}(\mathrm{I})$ can produce ROS participating in Fenton-type reactions; (Mechanism 7) copper toxicity can also be exhibited via displacement of iron from iron-sulfur clusters by $\mathrm{Cu}(\mathrm{I})$, leading to loss of protein function; (Mechanism 8) $\mathrm{Cu}(\mathrm{I})$ can lead to thiol depletion in the glutathione pool, and GS-Cu-SG can act as a copper donor for metalloenzymes under anaerobic conditions; (Mechanism 9) replacement of other metal cofactors by copper on several metalloproteins can promote mismetallation and inactivation of prey proteins. To protect from copper toxicity, (Mechanism 10) prey melanins can diminish the intracellular ROS burst triggered by $\mathrm{Cu}(\mathrm{I})$ and also sequester internal (Mechanism 11) and external (Mechanism 12) copper due to their metal affinity and high adsorption capacity. Abbreviations: GSH, reduced glutathione; GS, glutathionyl group; GSSG, oxidized, dimeric glutathione; ROS, reactive oxygen species; SG, glutathionyl group.

\section{ROLE OF COPPER IN BACTERIAL INTERACTIONS}

Transition metals, including iron, copper, manganese, and zinc, are essential trace nutrients in virtually all biological systems. Copper distribution in soil is influenced by climatic, physicochemical properties and possibly by exogenous inputs from volcanic eruptions, windblown dust, and forest fires. Soil copper levels are increased by anthropogenic sources including leather processing; municipal refuse; waste from electroplating and iron and steel production; and discarded copper products from plumbing, wiring, mining, vehicle traffic, and domestic heating $(39,111,146)$. Copper is also utilized in fungicides and herbicides for agricultural crops such as olives and grapes (4). Copper is also used as a feed additive and is excreted in animal feces that are used as manure to fertilize crops (137). In addition, copper-containing products are used in the manufacturing of hospital surfaces, surgical equipment, and other products used in medicine (83, 110, 135, 150). In 2008, the US Environmental Protection Agency recognized copper and its alloys as the first effective metallic antimicrobial agent. Nevertheless, these uses have led to the emergence of copper-tolerant microbes and the spread of resistance to other metals and antibiotics $(84,111,125)$.

\section{COPPER AS AN OFFENSIVE WEAPON IN BACTERIAL INTERACTIONS}


Copper toxicity has been implicated in interactions between protozoa and bacteria where eukaryotic organisms upregulate genes involved in copper handling and trafficking during phagocytosis and thereby induce accumulation of $\mathrm{Cu}(\mathrm{I})$ in the phagosome to kill bacteria $(52,61)$. In response, bacteria use mechanisms to survive inside of phagosomes such as digestion resistance and upregulation of expression of genes involved in copper detoxification $(46,49,80,143)$.

Copper is utilized for predation by the soil bacterium Cupriavidus necator (14, 15), a nonobligate predator that preys on a wide range of gram-positive and gram-negative bacteria (89, 163). C. necator not only is resistant to copper but also requires high copper concentrations for initial growth (but not subsequent growth). It produces a heat-stable copper-binding peptide growth initiation factor that is also used to kill its prey, such as the actinomycete Agromyces ramosus. A. ramosus counterattacks by producing mycelia that lyse approximately one-third of the C. necator cells. However, the surviving C. necator cells lyse A. ramosus mycelia using the excess copper delivered by the copper-binding peptide. Nevertheless, $C$. necator is unable to lyse the dormant rod cells that $A$. ramosus quickly forms and fragments from the mycelia. The dormant cells allow A. ramosus to grow again $(14,15)$. C. necator also preys on Bacillus subtilis, and its predatory activity increases in the presence of copper in a concentration-dependent manner. $C$. necator, in contrast to group predators, does not depend on outnumbering its prey, nor does its strategy require contact with its prey. This suggests that $C$. necator uses secreted extracellular factors to kill prey (136). B. subtilis forms spores to avoid predation by $C$. necator and other copper-using predatory bacteria such as Myxococcus xanthus $(100,101)$. A metabolically inactive state (i.e., a persister-like cell state) is sufficient for protection from $C$. necator, whereas an intact spore coat is required to resist predation by M. xanthus (136), indicating that the copper-dependent predatory system of the latter is more powerful than that of the former. M. xanthus exhibits a complex response to copper (117), which implies that numerous genes coding for structural elements are involved in efflux, complexation, and oxidation of copper (95, 96, 130). Expression of some genes increases after exposure to copper but rapidly decreases to basal levels, allowing an immediate response to the metal, whereas expression of other genes slows after copper addition 
and plateaus after $24-48 \mathrm{~h}$ as a maintenance response (94). This hierarchical response of $M$. xanthus to copper is controlled and coordinated by diverse and specific regulatory elements (57, 91, 131, 132). Since $M$. xanthus is not specifically resistant to copper, as are other bacteria, it has been suggested that some of the elements involved in the complex copper homeostasis of this bacterium might be required for its multicellular lifestyle (37). M. xanthus might use copper as an arsenal for cooperative predation to kill prey in a manner similar to that of eukaryotic predators, macrophages, and highly copper-resistant bacterial predators.

Unlike C. necator, M. xanthus requires cell-cell contact and close proximity for its predatory activity. This may be due to limited diffusion and/or the delivery mechanism used to lyse prey, and its predation might involve the participation of outer membrane vesicles (OMVs). Bacterial extracellular OMVs emerge after fission from the secreting cell. OMVs contain diverse cargo, including nucleic acids, proteins, lipids, virulence factors, and metabolites. A number of OMV functions have been demonstrated, including intercellular communication, procurement of nutrients, biofilm formation, modulation of host immune responses, delivery of toxins and virulence factors, and secretion of molecules $(6,13,25,42,92,147)$. Packaging within OMVs allows for a highly concentrated dose of molecules to be delivered to distant and inaccessible locations. Consequently, OMVs may enhance copper toxicity in bacterial interactions by concentrating the metal and ensure more focused transport and intervention of the metal during predatory activity, which would increase predation efficiency and reduce prey resistance (Figure $4 b)$.

Additionally, the predatory activity of $M$. xanthus has been recently demonstrated to involve copper accumulation in the region where the predator collides with the prey S. meliloti. Copper accumulation consequently upregulates expression of the $\mathrm{P}_{1 \mathrm{~B}}-\mathrm{ATPase}$ CopA, the multicopper oxidase CuoA, and the CBA efflux pump Cus2 in predator cells. Copper accumulation also triggers the prey to overproduce copper-inducible melanin at the predator-prey interface, which protects it from predation (Figure 4b) (37). 
Melanins are polymeric pigments found in all domains of life that have a wide variety of functions (38). They protect bacteria from environmental stress and influence bacterial interactions with other organisms (114). Melanins have the potential to scavenge free radicals so as to diminish oxidative bursts and protect bacteria from oxidative stress $(1,71)$ (Figure $4 b)$. Melanin production also has been proposed to help organisms cope with high concentrations of heavy metals (115) (Figure $4 \boldsymbol{b}$ ). This would mean that metals are less useful as antimicrobial drugs against melaninproducing organisms than they are against non-melanin-producing microbes (38). Importantly, melanins can also neutralize antibiotics, increasing the inhibitory dose of antibiotics and improving the viability of bacteria (86). In sum, melanins produced by prey during interaction with predators might be a crucial element of protection against predation, both helping the prey to cope with reactive oxygen species associated with potential copper toxicity and neutralizing the antibiotics released by the predator.

In the environment, copper may interfere in microbial interactions, modifying the activity of antibiotics produced by organisms and creating a variety of outcomes ranging from hindrance to enhancement of antibiotic activity (118). Copper may also modulate predator and prey antibiotic activity. Thus, predators could increase the toxicity of the metal, using it to enhance the antimicrobial activity of their own antibiotics and/or to neutralize antimicrobials released by the prey (Figure $4 \boldsymbol{b})$.

\section{DEFENSIVE PREY RESPONSES TO COPPER TOXICITY}

Interaction with a predator may prompt structural adaptations by prey that help to resist or escape predation. For example, mechanical barriers such as exopolysaccharide, mucus, andbiofilms (Figure 4a) are involved in neutralizing or counteracting copper toxicity $(44,106,116)$.

Bacterial biofilms confer resistance to antibiotics and to metals (including copper) $(63,65$, $145,162)$. However, bacterial predators can use copper to cause an unspecific reduction of expression of biofilm-matrix-promoting genes of prey. This results in changes in both the biofilm surface roughness and wetting behavior, producing biofilms that are more susceptible to treatment 
with aqueous antibiotic solutions $(45,62)$. During their attack, consequently, bacterial predators may use not only the inherent toxicity of copper but also the ability of this metal to prevent biofilm formation by the prey and weaken the defensive features of existing biofilms. This increases susceptibility of the prey population to the arsenal of lytic products released by the predators. In fact, the dual roles of copper and other metals as biofilm inhibitors and antimicrobial agents have been widely explored $(45,47,67,83,141)$.

Nevertheless, in addition to biofilms exhibiting a protective role against metals, metals induce the generation of biofilms, as in the case of the plant pathogen Xylella fastidiosa (36). Copper selection of dormant persisters has also been described in $X$. fastidiosa. The pretreatment of biofilms with a subinhibitory concentration of copper increases the number of persisters recovered following treatment with toxic copper levels (104). Similarly, metal-selected persisters in biofilms of Pseudomonas aeruginosa may be responsible for increased metal tolerance after short-term exposure to copper or zinc (64). Altogether these results support the hypothesis that metal selection of persisters is responsible for biofilm tolerance to metals, and particularly to copper (Figure $\mathbf{4 a}$ ). Copper has also been shown to induce so-called viable nonculturable cells, which are in a stressinduced, dormant state, of a variety of gram-negative bacteria, including E. coli, $P$. aeruginosa, and Salmonella enterica serovar Typhi (3, 48, 68). Additionally, as mentioned above for the interaction of B. subtilis with $C$. necator or $M$. xanthus, differentiation of prey to vegetative, stressresistant spores avoids predation $(100,101,136)$ (Figure 4a).

The processes of bacterial differentiation discussed above reflect diverse approaches adopted by prey to manage natural or predator-induced copper toxicity. Some of these tactics may enable the establishment of a physical barrier to prevent prey from acquiring copper, whereas other defensive methods hinge on conversion of vegetative cells to cellular types exhibiting more resistance to copper.

\section{PROTECTIVE ROLE OF CHALKOPHORES (AND OTHER METALLOPHORES) AGAINST COPPER TOXICITY}


Metallophores are a surprising component of prey defensive equipment against copper (Figure 4b). Metallophores are considered primarily in the context of their role in metal uptake and metal homeostasis, but many appear to have a broad range of secondary roles, ranging from regulatory functions (75) to protection against toxicity caused by metals (155) or reactive oxygen species (33) to biomedically relevant antibiotic or therapeutic functions $(70,77,85)$.

Although metallophores have been identified for diverse metals, including manganese (113), nickel and cobalt (54), zinc (7), gold (69), and even molybdenum and vanadium (153), best characterized are siderophores, small iron-binding natural products that are secreted from cells and bind extracellular iron with high affinity (81). Iron-bound siderophores are then taken back up into the cell, where the iron is liberated from the compound and incorporated into the cellular iron pool (124). Strategies similar to microbial active iron uptake using siderophores also exist in fungi and plants $(10,59)$.

Nevertheless, as indicated above, this strategy is not limited to iron. In a number of bacteria, production and deployment of metallophores satisfy needs for other metals, mitigate metal deficiencies, or even defend against metal toxicity $(70,77)$. The best-studied family of noniron metallophores are chalkophores (chalkos is Greek for copper), a family of copper-binding natural products that exhibit great affinity and specificity to this metal (74). The largest and bestunderstood group of chalkophores is methanobactins (Mbns). Mbns have an exceedingly high affinity for copper and bind copper from soluble or mineral sources upon secretion $(41,72)$. Although Mbns were originally identified in methanotrophic bacteria, which require large amounts of copper, there is genomic evidence for their production in a wider range of bacteria, spanning both gram-negative and gram-positive bacteria (41, 72, 73); fungi; and algae (164).

Mbns may have an important role in bacterial interactions due to their ability to not only bind copper but also reductively bind $\mathrm{Cu}(\mathrm{II})$ (60), producing copper-bound Mbn (CuMbn), which has oxidase, superoxide dismutase (SOD), and hydrogen peroxide reductase activities (33). Extracellular SOD activity of CuMbns secreted by prey may be biologically important and have a 
relevant defensive role against the oxidative stress associated with the offensive use of copper by bacterial predators.

Yersiniabactin (Ybt), an iron-binding natural product produced of Yersinia pestis, binds $\mathrm{Cu}(\mathrm{II})$ competitively with $\mathrm{Fe}(\mathrm{III})$. Interestingly, Ybt is used for copper uptake and as a mechanism to mitigate copper-mediated damage in bacteria $(74,109)$. Ybt protects against copper toxicity during human infection by uropathogenic E. coli (18). When iron is limited, uropathogenic E. coli produces catecholate siderophores that are highly efficient $\mathrm{Fe}$ (III) chelators but are also responsible for catecholate-mediated reduction of $\mathrm{Cu}(\mathrm{II})$ to the more bactericidal form $\mathrm{Cu}(\mathrm{I})$. Nevertheless, $\mathrm{Cu}(\mathrm{II})$ sequestration by $\mathrm{Ybt}$ protects from catecholate-mediated toxic $\mathrm{Cu}(\mathrm{I})$ formation, so $E$. coli isolates that produce Ybt are more resistant to copper. In addition, isolates that do not produce Ybt but are supplemented with purified Ybt regain resistance to toxic levels of copper (18). Like CuMbn, copper-bound Ybt (CuYbt) exhibits SOD activity, potentially providing protection against phagocytic killing (19). The ability of Ybt to protect E. coli from copper toxicity and redox-based phagocyte defenses distinguishes it from other siderophores in $E$. coli (76). These results lay out the possibility that secreted copper-binding molecules evolved in pathogens to neutralize the antibacterial activity of copper.

The siderophores pyochelin (Pch) and pyoverdine (Pvd), which are produced by P. aeruginosa, are also capable of binding a range of divalent metal ions, including copper and zinc. These. The synthesis of these $P$. aeruginosa virulence-associated siderophores increases copper resistance and alters the dynamics and the ecotoxicity of copper in soil (40). Additionally, as with Ybt, Pch and Pvd may sequester copper outside of the cell, playing a protective role against copper toxicity. (8). Consequently, copper binding that does not result in copper uptake may be a biologically relevant function of several siderophores (72) and may be a defensive strategy of prey to face the potential copper toxicity employed by predators (Figure $4 b$ ).

In the environment, metallophores produced by bacteria are sometimes utilized by other nearby microbes, such as fungi and other bacterial species, to promote their growth $(5,16,58,97,149)$. copper piracy has also been speculated to occur in methanotrophic communities with a high 
demand for copper, where Mbns, in addition to binding copper, also serve as interspecies signaling molecules $(50,151)$. Further studies are necessary to determine whether copper competition triggers synthesis of secondary metabolites or, even more interestingly, induces genes responsible for production of yet unknown compounds involved in microbial interactions.

\section{DISCLOSURE STATEMENT}

The authors are not aware of any affiliations, memberships, funding, or financial holdings that might be perceived as affecting the objectivity of this review.

\section{ACKNOWLEDGEMENTS}

The research was financially supported by gramts from the National Natural Science Foundation of China (No. 31770123) and the International Cooperation science Foundation of Fujian Agriculture and Forestry University (No. KXGH17013) to C.R., by NSF BIO/MCB grant 1817962 to M.Y. by NIH grants R35GM136211 and R01GM55425 to B.P.R., and by Spanish Government grants BFU2016-75425-P (70\% funded by FEDER) and PID2020-112634GB-I00 to AMM.

\section{LITERATURE CITED}

1. Ahmad S, Lee SY, Kong HG, Jo EJ, Choi HK, et al. 2016. Genetic determinants for pyomelanin production and its protective effect against oxidative stress in Ralstonia solanacearum. PLOS ONE 11:e0160845

2. Argüello JM, Patel SJ, Quintana J. 2016. Bacterial $\mathrm{Cu}^{+}$-ATPases: models for molecular structure-function studies. Metallomics 8:906-14 
3. Aurass P, Prager R, Flieger A. 2011. EHEC/EAEC O104:H4 strain linked with the 2011 German outbreak of haemolytic uremic syndrome enters into the viable but non-culturable state in response to various stresses and resuscitates upon stress relief. Environ. Microbiol. 13:313948

4. Ballabio C, Panagos P, Lugato E, Huang JH, Orgiazzi A, et al. 2018. Copper distribution in European top soils: an assessment based on Lucas soil survey. Sci. Total. Environ. 636:28298

5. Barber MF, Elde NC. 2015. Buried treasure: evolutionary perspectives on microbial iron piracy. Trends Genet. 31:627-36

6. Bitto NJ, Chapman R, Pidot S, Costin A, Lo C, et al. 2017. Bacterial membrane vesicles transport their DNA cargo into host cells. Sci. Rep. 7:7072

7. Bobrov A, Kirillina O, Fetherston J, Miller C, Burlison J, Perry R. 2014. The Yersinia pestis siderophore, yersiniabactin, and the ZnuABC system both contribute to zinc acquisition and the development of lethal septicemic plague in mice. Mol. Microbiol. 93(4):759-75

8. Braud A, Geoffroy V, Hoegy F, Mislin G, Schalk I. 2010. Presence of the siderophores pyoverdine and pyochelin in the extracellular medium reduces toxic metal accumulation in Pseudomonas aeruginosa and increases bacterial metal tolerance. Environ. Microbiol. Rep. 2:419-25

9. Breuer C, Pichler T. 2013. Arsenic in marine hydrothermal fluids. Chem. Geol. 348:2-14

10. Buděšínský M, Budzikiewicz H, Procházka Ž, Ripperger H, Römer A, et al. 1980. Nicotianamine, a possible phytosiderophore of general occurrence. Phytochemistry 19:229597

11. Burckhardt RM, Escalante-Semerena JC. 2020. Small-molecule acetylation by GCN5-belated N-acetyltransferases in bacteria. Microbiol. Mol. Biol. Rev. 84:e00090-19

12. Callac N, Posth NR, Rattray JE, Yamoah KKY, Wiech A, et al. 2017. Modes of carbon fixation in an arsenic and $\mathrm{CO}_{2}$-rich shallow hydrothermal ecosystem. Sci. Rep. 7:14708 
13. Caruana JC, Walper SA. 2020. Bacterial membrane vesicles as mediators of microbe-microbe and microbe-host community interactions. Front. Microbiol. 11:432

14. Casida LE. 1987. Relation to copper of N-1, a nonobligate bacterial predator. Appl. Environ. Microbiol. 53:1515-18

15. Casida LE. 1988. Minireview: nonobligate bacterial predation of bacteria in soil. Microb. Ecol. $15: 1-8$

16. Challenger F. 1951. Biological methylation. In Advances in Enzymology and Related Subjects of Biochemistry, ed. FF Nord, pp. 429-91. Interscience: NY

17. Chandrangsu P, Rensing C, Helmann J. 2017. Metal homeostasis and resistance in bacteria. Nat. Rev. Microbiol. 6:338-50

18. Chaturvedi KS, Hung CS, Crowley JR, Stapleton AE, Henderson JP. 2012. The siderophore yersiniabactin binds copper to protect pathogens during infection. Nat. Chem. Biol. 8:731-36

19. Chaturvedi KS, Hung CS, Giblin DE, Urushidani S, Austin AM, et al. 2014. Cupric yersiniabactin is a virulence-associated superoxide dismutase mimic. ACS Chem. Biol. 9:55161

20. Chauhan NS, Ranjan R, Purohit HJ, Kalia VC, Sharma R. 2009. Identification of genes conferring arsenic resistance to Escherichia coli from an effluent treatment plant sludge metagenomic library. FEMS Microbiol. Ecol. 67:130-39

21. Chen J, Bhattacharjee H, Rosen BP. 2015. ArsH is an organoarsenical oxidase that confers resistance to trivalent forms of the herbicide monosodium methylarsenate and the poultry growth promoter roxarsone. Mol. Microbiol. 96:1042-52

22. Chen J, Rosen BP. 2020. The Pseudomonas putida NfnB nitroreductase confers resistance to roxarsone. Sci. Total. Environ. 748:141339

23. Chen J, Yoshinaga M, Rosen BP. 2019. The antibiotic action of methylarsenite is an emergent property of microbial communities. Mol. Microbiol. 111:487-94

24. Chen J, Zhang J, Rosen BP. 2019. Role of ArsEFG in roxarsone and nitarsone detoxification and resistance. Environ. Sci. Technol. 53:6182-91 
25. Chen L, Valentine JL, Huang CJ, Endicott CE, Moeller TD, et al. 2016. Outer membrane vesicles displaying engineered glycotopes elicit protective antibodies. PNAS 113:E3609-18

26. Chen SC, Sun GX, Rosen BP, Zhang SY, Deng Y, et al. 2017. Recurrent horizontal transfer of arsenite methyltransferase genes facilitated adaptation of life to arsenic. Sci. Rep. 7:7741

27. Chen SC, Sun GX, Yan Y, Konstantinidis KT, Zhang SY, et al. 2020. The Great Oxidation Event expanded the genetic repertoire of arsenic metabolism and cycling. PNAS 117:1041421

28. Chi Fru E, Arvestål E, Callac N, El Albani A, Kilias S, et al. 2015. Arsenic stress after the Proterozoic glaciations. Sci. Rep. 5:17789

29. Chi Fru E, Callac N, Posth NR, Argyraki A, Ling YC, et al. 2018. Arsenic and high affinity phosphate uptake gene distribution in shallow submarine hydrothermal sediments. Biogeochemistry 141:41-62

30. Chi Fru E, Ivarsson M, Kilias SP, Bengtson S, Belivanova V, et al. 2013. Fossilized iron bacteria reveal a pathway to the biological origin of banded iron formation. Nat. Commun. 4:2050

31. Chi Fru E, Rodríguez NP, Partin CA, Lalonde SV, Andersson P, et al. 2016. Cu isotopes in marine black shales record the Great Oxidation Event. PNAS 113:4941-46

32. Chi Fru E, Somogyi A, El Albani A, Medjoubi K, Aubineau J, et al. 2019. The rise of oxygendriven arsenic cycling at ca. 2.48 Ga. Geology 47:243-46

33. Choi DW, Semrau JD, Antholine WE, Hartsel SC, Anderson RC, et al. 2008. Oxidase, superoxide dismutase, and hydrogen peroxide reductase activities of methanobactin from types I and II methanotrophs. J. Inorg. Biochem. 102:1571-80

34. Ciscato E, Bontognali T, Poulton S, Vance D. 2019. Copper and its isotopes in organic-rich sediments: from the modern Peru Margin to Archean shales. Geosciences 9:325

35. Clokie MRJ, Millard AD, Letarov AV, Heaphy S. 2011. Phages in nature. Bacteriophage 1:3145 
36. Cobine P, Cruz L, Navarrete F, Duncan D, Tygart M, Fuente L. 2013. Xylella fastidiosa differentially accumulates mineral elements in biofilm and planktonic cells. PLOS ONE 8:e54936

37. Contreras-Moreno FJ, Muñoz-Dorado J, García-Tomsig NI, Martínez-Navajas G, Pérez J, Moraleda-Muñoz A. 2020. Copper and melanin play a role in Myxococcus xanthus predation on Sinorhizobium meliloti. Front. Microbiol. 11:94

38. Cordero RJ, Casadevall A. 2017. Functions of fungal melanin beyond virulence. Fungal Biol. Rev. 31:99-112

39. Cornu JY, Huguenot D, Jézéquel K, Lollier M, Lebeau T. 2017. Bioremediation of coppercontaminated soils by bacteria. J. Microbiol. Biotechnol. 33:26

40. Cornu JY, Randriamamonjy S, Gutierrez M, Rocco K, Gaudin P, et al. 2019. Copper phytoavailability in vineyard topsoils as affected by pyoverdine supply. Chemosphere $236: 124347$

41. Dassama LM, Kenney GE, Ro SY, Zielazinski EL, Rosenzweig AC. 2016. Methanobactin transport machinery. PNAS 113:13027-32

42. Deatherage BL, Cookson BT. 2012. Membrane vesicle release in bacteria, eukaryotes, and archaea: a conserved yet underappreciated aspect of microbial life. Infect. Immun. 80:1948-57

43. Delmar JA, Su CC, Yu EW. 2014. Bacterial multidrug efflux transporters. Annu. Rev. Biophys. 43:93-117

44. DePas WH, Syed AK, Sifuentes M, Lee JS, Warshaw D, et al. 2014. Biofilm formation protects Escherichia coli against killing by Caenorhabditis elegans and Myxococcus xanthus. Appl. Environ. Microbiol. 80:7079-87

44a. Diamond CW, Lyons TW. 2018. Mid-Proterozoic redox evolution and the possibility of transient oxygenation events. Emerg. Top. Life Sci. 2:235-45

45. Dinh TL, Akhmetova GR, Martykanova DS, Rudakova NL, Sharipova MR. 2019. Influence of divalent metal ions on biofilm formation by Bacillus subtilis. BioNanoScience 9:521-27 
46. Djoko KY, Ong CY, Walker MJ, McEwan AG. 2015. The role of copper and zinc toxicity in innate immune defense against bacterial pathogens. J. Biol. Chem. 290:18954-61

47. Dupont CL, Grass G, Rensing C. 2011. Copper toxicity and the origin of bacterial resistancenew insights and applications. Metallomics 3:1109-18

48. Dwidjosiswojo Z, Richard J, Moritz MM, Dopp E, Flemming HC, Wingender J. 2011. Influence of copper ions on the viability and cytotoxicity of Pseudomonas aeruginosa under conditions relevant to drinking water environments. Int. J. Hyg. Environ. Health. 214:485-92

48a. Ebrahim GJ. 2010. Bacterial resistance to antimicrobials. J. Trop. Pediatr. 56:141-143

49. Espinoza-Vergara G, Hoque MM, McDougald D, Noorian P. 2020. The impact of protozoan predation on the pathogenicity of Vibrio cholerae. Front. Microbiol. 11:17

50. Farhan Ul-Haque M, Kalidass B, Vorobev A, Baral BS, DiSpirito AA, Semrau JD. 2015. Methanobactin from Methylocystis sp. strain SB2 affects gene expression and methane monooxygenase activity in Methylosinus trichosporium OB3b. Appl. Environ. Microbiol. $81: 2466-73$

51. Garbinski LD, Rosen BP, Chen J. 2019. Pathways of arsenic uptake and efflux. Environ. Int. 126:585-97

51a. Garbinski LD, Rosen BP, Yoshinaga M. 2020. Organoarsenicals inhibit bacterial peptidoglycan biosynthesis by targeting the essential enzyme MurA. Chemosphere $254: 126911$

52. German N, Doyscher D, Rensing C. 2013. Bacterial killing in macrophages and amoeba: Do they all use a brass dagger? Future Microbiol. 8:1257-64

53. Ghoul M, Mitri S. 2016. The ecology and evolution of microbial competition. Trends Microbiol. 24:833-45

54. Ghssein G, Brutesco C, Ouerdane L, Fojcik C, Izaute A, et al. 2016. Biosynthesis of a broadspectrum nicotianamine-like metallophore in Staphylococcus aureus. Science 352:1105-9 
55. Gibaud S, Jaouen G. 2010. Arsenic-based drugs: from Fowler's solution to modern anticancer chemotherapy. In Medicinal Organometallic Chemistry, ed. S Gibaud, G Jaouen. Berlin: Springer. https://doi.org/10.1007/978-3-642-13185-1_1

56. Giovannoni SJ, Halsey KH, Saw J, Muslin O, Suffridge CP, et al. 2019. A parasitic arsenic cycle that shuttles energy from phytoplankton to heterotrophic bacterioplankton. mBio 10:e00246-19

57. Gómez-Santos N, Pérez J, Sánchez-Sutil MC, Moraleda-Muñoz A, Muñoz-Dorado J. 2011. CorE from Myxococcus xanthus is a copper-dependent RNA polymerase sigma factor. PLOS Genet. 7:e1002106

58. Grinter R, Leung PM, Wijeyewickrema LC, Littler D, Beckham S, et al. 2019. Proteaseassociated import systems are widespread in Gram-negative bacteria. PLOS Genet. 15:e1008435

59. Haas H, Eisendle M, Turgeon BG. 2008. Siderophores in fungal physiology and virulence. Annu. Rev. Phytopathol. 46:149-87

60. Hakemian AS, Tinberg CE, Kondapalli KC, Telser J, Hoffman BM, et al. 2005. The copper chelator methanobactin from Methylosinus trichosporium OB3b binds copper(I). J. Am. Chem. Soc. $127: 17142-43$

61. Hao X, Lüthje F, Rønn R, German NA, Li X, et al. 2016. A role for copper in protozoan grazing - two billion years selecting for bacterial copper resistance. Mol. Microbiol. 102:62841

62. Harris T, Heidary N, Kozuch J, Frielingsdorf S, Lenz O, et al. 2018. In situ spectroelectrochemical studies into the formation and stability of robust diazonium-derived interfaces on gold electrodes for the immobilization of an oxygen-tolerant hydrogenase. ACS Appl. Mater. Interfaces 10:23380-91

63. Harrison JJ, Ceri H, Stremick CA, Turner RJ. 2004. Biofilm susceptibility to metal toxicity. Environ. Microbiol. 6:1220-27 
64. Harrison JJ, Turner RJ, Ceri H. 2005. Persister cells, the biofilm matrix and tolerance to metal cations in biofilm and planktonic Pseudomonas aeruginosa. Environ. Microbiol. 7:981-94

65. Høiby N, Bjarnsholt T, Givskov M, Molin S, Ciofu O. 2010. Antibiotic resistance of bacterial biofilms. Int. J. Antimicrob. Agents 35:322-32

66. Horsman GP, Zechel DL. 2017. Phosphonate biochemistry. Chem. Rev. 117:5704-83

67. Hsueh YH, Ke WJ, Hsieh CT, Lin KS, Tzou DY, Chiang CL. 2015. ZnO nanoparticles affect Bacillus subtilis cell growth and biofilm formation. PLOS ONE 10:e0128457

68. Jiang L. 2014. Low temperature and copper induce viable but nonculturable state of Salmonella typhi in the bottled drinking water. Adv. Mater. Res. 893:492-95

69. Johnston CW, Wyatt MA, Li X, Ibrahim A, Shuster J, et al. 2013. Gold biomineralization by a metallophore from a gold-associated microbe. Nat. Chem. Biol. 9:241-43

70. Johnstone TC, Nolan EM. 2015. Beyond iron: non-classical biological functions of bacterial siderophores. Dalton. Trans. 44:6320-39

71. Keith KE, Killip L, He P, Moran GR, Valvano MA. 2007. Burkholderia cenocepacia C5424 produces a pigment with antioxidant properties using a homogentisate intermediate. $J$. Bacteriol. 189:9057-65

72. Kenney GE, Dassama LMK, Pandelia ME, Gizzi AS, Martinie RJ, et al. 2018. The biosynthesis of methanobactin. Science 359:1411-16

73. Kenney GE, Rosenzweig AC. 2013. Genome mining for methanobactins. BMC Biol. 11:17

74. Kenney GE, Rosenzweig AC. 2018. Chalkophores. Annu. Rev. Biochem. 87:645-76

75. Kenney GE, Sadek M, Rosenzweig AC. 2016. Copper-responsive gene expression in the methanotroph Methylosinus trichosporium OB3b. Metallomics 8:931-40

76. Koh EI, Henderson JP. 2015. Microbial copper-binding siderophores at the host-pathogen interface. Aquat. Geochem. 290:18967-74

77. Kraemer SM, Duckworth OW, Harrington JM, Schenkeveld WD. 2015. Metallophores and trace metal biogeochemistry. Aquat. Geochem. 21:159-95 
78. Kritharis A, Bradley TP, Budman DR. 2013. The evolving use of arsenic in pharmacotherapy of malignant disease. Ann. Hematol. 92:719-30

79. Kuramata M, Sakakibara F, Kataoka R, Yamazaki K, Baba K, et al. 2016. Arsinothricin, a novel organoarsenic species produced by a rice rhizosphere bacterium. Environ. Chem. 13(4):723-31

80. Ladomersky E, Petris MJ. 2015. Copper tolerance and virulence in bacteria. Metallomics 7:957-64

81. Lankford CE, Byers BR. 1973. Bacterial assimilation of iron. CRC Crit. Rev. Microbiol. $2: 273-331$

82. Large RR, Mukherjee I, Gregory D, Steadman J, Corkrey R, Danyushevsky LV. 2019. Atmosphere oxygen cycling through the Proterozoic and Phanerozoic. Miner. Depos. 54:485506

Large RR. 2020. Evolution of Earth's atmosphere. In Encyclopedia of Geology, ed. S Elias, D Alderton. Amsterdam: Elsevier. 2nd ed.

83. Lemire JA, Harrison JJ, Turner RJ. 2013. Antimicrobial activity of metals: mechanisms, molecular targets and applications. Nat. Rev. Microbiol. 11:371-84

84. Li LG, Xia Y, Zhang T. 2017. Co-occurrence of antibiotic and metal resistance genes revealed in complete genome collection. ISME J. 11:651-62

85. Lichtmannegger J, Leitzinger C, Wimmer R, Schmitt S, Schulz S, et al. 2016. Methanobactin reverses acute liver failure in a rat model of Wilson disease. J. Microbiol. Immunol. Infect. $126: 2721-35$

86. Lin WP, Lai HL, Liu YL, Chiung YM, Shiau CY, et al. 2005. Effect of melanin produced by a recombinant Escherichia coli on antibacterial activity of antibiotics. J. Microbiol. Immunol. Infect. 38:320-26

87. Lonetto MA, Donohue TJ, Gross CA, Buttner MJ. 2019. Discovery of the extracytoplasmic function $\sigma$ factors. Mol. Microbiol. 112:348-55 
88. Lyons TW, Reinhard CT, Planavsky NJ. 2014. The rise of oxygen in Earth's early ocean and atmosphere. Nature 506:307-15

89. Makkar NS, Casida LE. 1987. Technique for estimating low numbers of a bacterial strain(s) in soil. Appl. Environ. Microbiol. 53:887-88

90. Mangalgiri KP, Adak A, Blaney L. 2015. Organoarsenicals in poultry litter: detection, fate, and toxicity. Environ. Int. 75:68-80

91. Marcos-Torres FJ, Pérez J, Gómez-Santos N, Moraleda-Muñoz A, Muñoz-Dorado J. 2016. In depth analysis of the mechanism of action of metal-dependent sigma factors: characterization of CorE2 from Myxococcus xanthus. Nucleic. Acids. Res. 44:5571-84

92. Mashburn LM, Whiteley M. 2005. Membrane vesicles traffic signals and facilitate group activities in a prokaryote. Nature 437:422-25

93. Moore EK, Jelen BI, Giovannelli D, Raanan H, Falkowski PG. 2017. Metal availability and the expanding network of microbial metabolisms in the Archaean eon. Nat. Geosci. 10:62936

94. Moraleda-Muñoz A, Marcos-Torres FJ, Pérez J, Muñoz-Dorado J. 2019. Metal-responsive RNA polymerase extracytoplasmic function (ECF) sigma factors. Mol. Microbiol. 112:38598

95. Moraleda-Muñoz A, Pérez J, Extremera AL, Muñoz-Dorado J. 2010. Differential regulation of six heavy metal efflux systems in the response of Myxococcus xanthus to copper. Appl. Environ. Microbiol. 76:6069-76

96. Moraleda-Muñoz A, Pérez J, Extremera AL, Muñoz-Dorado J. 2010. Expression and physiological role of three Myxococcus xanthus copper-dependent $\mathrm{P}_{1 \mathrm{~B}}$-type ATPases during bacterial growth and development. Appl. Environ. Microbiol. 76:6077-84

97. Mozzi A, Forni D, Clerici M, Cagliani R, Sironi M. 2018. The diversity of mammalian hemoproteins and microbial heme scavengers is shaped by an arms race for iron piracy. Front. Immunol. 9:2086 
98. Mukhopadhyay R, Bhattacharjee H, Rosen BP. 2014. Aquaglyceroporins: generalized metalloid channels. Biochim. Biophys. Acta Gen. Subj. 1840:1583-91

99. Deleted in proof

100. Müller S, Strack SN, Hoefler BC, Straight PD, Kearns DB, Kirby JR. 2014. Bacillaene and sporulation protect Bacillus subtilis from predation by Myxococcus xanthus. Appl. Environ. Microbiol. 80:5603-10

101. Müller S, Strack SN, Ryan SE, Kearns DB, Kirby JR. 2015. Predation by Myxococcus xanthus induces Bacillus subtilis to form spore-filled megastructures. Appl. Environ. Microbiol. $81: 203-10$

102. Deleted in proof

103. Munita JM, Arias CA. 2016. Mechanisms of antibiotic resistance. Microbiology spectrum 4(2):4.2.15. https://doi.org/10.1128/microbiolspec.VMBF-0016-2015

104. Muranaka LS, Takita MA, Olivato JC, Kishi LT, de Souza AA. 2012. Global expression profile of biofilm resistance to antimicrobial compounds in the plant-pathogenic bacterium Xylella fastidiosa reveals evidence of persister cells J. Bacteriol. 194:4561-69

105. Nadar VS, Chen J, Dheeman DS, Galván AE, Yoshinaga-Sakurai K, et al. 2019. Arsinothricin, an arsenic-containing non-proteinogenic amino acid analog of glutamate, is a broad-spectrum antibiotic. Commun. Biol. 2:131

106. Nair RR, Vasse M, Wielgoss S, Sun L, Yu Y-TN, Velicer GJ. 2019. Bacterial predator-prey coevolution accelerates genome evolution and selects on virulence-associated prey defences. Nat. Commun. 10:4301

107. Narbonne GM. 2004. The Ediacara biota: neoproterozoic origin of animals and their ecosystems. Annu. Rev. Earth. Planet. Sci. 33:421-42

108. Nies DH. 2003. Efflux-mediated heavy metal resistance in prokaryotes. FEMS Microbiol. Rev. 27:313-39

109. Nolan EM. 2017. A noncanonical role for yersiniabactin in bacterial copper acquisition. Biochemistry 56:6073-74 
110. Page K, Wilson M, Parkin IP. 2009. Antimicrobial surfaces and their potential in reducing the role of the inanimate environment in the incidence of hospital-acquired infections. J. Mater. Chem. 19:3819-31

111. Pal C, Asiani K, Arya S, Rensing C, Stekel DJ, et al. 2017. Metal resistance and its association with antibiotic resistance. 70:261-313

112. Papkou A, Guzella T, Yang W, Koepper S, Pees B, et al. 2019. The genomic basis of Red Queen dynamics during rapid reciprocal host-pathogen coevolution. PNAS 116:923-28

113. Parker DL, Lee SW, Geszvain K, Davis RE, Gruffaz C, et al. 2014. Pyoverdine synthesis by the Mn(II)-oxidizing bacterium Pseudomonas putida GB-1. Front. Microbiol. 5:202

114. Pavan ME, Lopez NI, Pettinari MJ. 2020. Melanin biosynthesis in bacteria, regulation and production perspectives. Appl. Microbiol. Biotechnol. 104:1357-70

115. Pavan ME, Pavan EE, Lopez NI, Levin L, Pettinari MJ. 2015. Living in an extremely polluted environment: clues from the genome of melanin-producing Aeromonas salmonicida subsp. pectinolytica $34 \mathrm{mel}^{\mathrm{T}}$. Appl. Environ. Microbiol. 81:5235-48

116. Pérez J, Jiménez-Zurdo JI, Martínez-Abarca F, Millán V, Shimkets LJ, Muñoz-Dorado J. 2014. Rhizobial galactoglucan determines the predatory pattern of Myxococcus xanthus and protects Sinorhizobium meliloti from predation. Environ. Microbiol. 16:2341-50

117. Pérez J, Muñoz-Dorado J, Moraleda-Muñoz A. 2018. The complex global response to copper in the multicellular bacterium Myxococcus xanthus. Metallomics 10:876-86

118. Poole K. 2017. At the nexus of antibiotics and metals: the impact of $\mathrm{Cu}$ and $\mathrm{Zn}$ on antibiotic activity and resistance. Trends Microbiol. 25:820-32

119. Poulton SW, Canfield DE. 2011. Ferruginous conditions: a dominant feature of the ocean through Earth's history. Elements 7:107-12

120. Deleted in proof

121. Rademacher C, Masepohl B. 2012. Copper-responsive gene regulation in bacteria. Microbiology 158:2451-64 
122. Radke B, Jewell L, Piketh S, Namieśnik J. 2014. Arsenic-based warfare agents: production, use, and destruction. Crit. Rev. Environ. Sci. Technol. 44:1525-76

123. Rascovan N, Maldonado J, Vazquez MP, Farías ME. 2016. Metagenomic study of red biofilms from Diamante Lake reveals ancient arsenic bioenergetics in haloarchaea. ISME J. 10:299-309

124. Raymond KN, Allred BE, Sia AK. 2015. Coordination chemistry of microbial iron transport. Accounts Chem. Res. 48:2496-505

125. Rensing C, Moodley A, Cavaco LM, McDevitt SF. 2018. Resistance to metals used in $\begin{array}{llll}\text { agricultural } & \text { production. } & \text { Microbiol. } & \text { Spec. }\end{array}$ https://doi.org/10.1128/microbiolspec.ARBA-0025-2017

126. Ridge PG, Zhang Y, Gladyshev VN. 2008. Comparative genomic analyses of copper transporters and cuproproteomes reveal evolutionary dynamics of copper utilization and its link to oxygen. PLOS ONE 3:e1378

127. Robbins LJ, Lalonde SV, Planavsky NJ, Partin CA, Reinhard CT, et al. 2016. Trace elements at the intersection of marine biological and geochemical evolution. Earth-Sci. Rev. 163:32348

128. Robinson NJ, Winge DR. 2010. Copper metallochaperones. Annu. Rev. Biochem. 79:537-62

129. Rutherford DW, Bednar AJ, Garbarino JR, Needham R, Staver KW, Wershaw RL. 2003. Environmental fate of roxarsone in poultry litter. Part II. Mobility of arsenic in soils amended with poultry litter. Environ. Sci. Technol. 37:1515-20

130. Sánchez-Sutil MC, Gómez-Santos N, Moraleda-Muñoz A, Martins LO, Pérez J, MuñozDorado J. 2007. Differential expression of the three multicopper oxidases from Myxococcus xanthus. J. Bacteriol. 189:4887-98

131. Sánchez-Sutil MC, Marcos-Torres FJ, Pérez J, Ruiz-González M, García-Bravo E, et al. 2016. Dissection of the sensor domain of the copper-responsive histidine kinase CorS from Myxococcus xanthus. Environ. Microbiol. Rep. 8:363-70 
132. Sánchez-Sutil MC, Pérez J, Gómez-Santos N, Shimkets LJ, Moraleda-Muñoz A, MuñozDorado J. 2013. The Myxococcus xanthus two-component system CorSR regulates expression of a gene cluster involved in maintaining copper tolerance during growth and dvelopment. PLOS ONE 8:e68240

133. Sancho-Tomás M, Somogyi A, Medjoubi K, Bergamaschi A, Visscher PT, et al. 2018. Distribution, redox state and (bio)geochemical implications of arsenic in present day microbialites of Laguna Brava, Salar de Atacama. Chem. Geol. 490:13-21

134. Sanders OI, Rensing C, Kuroda M, Mitra B, Rosen BP. 1997. Antimonite is accumulated by the glycerol facilitator GlpF in Escherichia coli. J. Bacteriol. 179:3365-67

135. Schmidt MG, von Dessauer B, Benavente C, Benadof D, Cifuentes P, et al. 2016. Copper surfaces are associated with significantly lower concentrations of bacteria on selected surfaces within a pediatric intensive care unit. Am. J. Infect. Control 44:203-9

136. Seccareccia I, Kovács ÁT, Gallegos-Monterrosa R, Nett M. 2016. Unraveling the predatorprey relationship of Cupriavidus necator and Bacillus subtilis. Microbiol. Res. 192:231-38

137. Seiler C, Berendonk TU. 2012. Heavy metal driven co-selection of antibiotic resistance in soil and water bodies impacted by agriculture and aquaculture. Front. Microbiol. 3:399

138. Sharma I. 2012. Arsenic induced oxidative stress in plants. Biologia 67:447-53

139. Shen S, Li XF, Cullen WR, Weinfeld M, Le XC. 2013. Arsenic binding to proteins. Chem. Rev. 113:7769-92

140. Shi K, Li C, Rensing C, Dai X, Fan X, Wang G. 2018. Efflux transporter ArsK is responsible for bacterial resistance to arsenite, antimonite, trivalent roxarsone, and methylarsenite. Appl. Environ. Microbiol. 84:e01842-18

141. Sirelkhatim A, Mahmud S, Seeni A, Kaus NHM, Ann LC, et al. 2015. Review on zinc oxide nanoparticles: antibacterial activity and toxicity mechanism. Nano-Micro. Lett. 7:219-42

142. Deleted in proof

143. Sun S, Noorian P, McDougald D. 2018. Dual role of mechanisms involved in resistance to predation by protozoa and virulence to humans. Front. Microbiol. 9:1017 
144. Taylor V, Goodale B, Raab A, Schwerdtle T, Reimer K, et al. 2017. Human exposure to organic arsenic species from seafood. Sci. Total Environ. 580:266-82

145. Teitzel GM, Parsek MR. 2003. Heavy metal resistance of biofilm and planktonic Pseudomonas aeruginosa. Appl. Environ. Microbiol. 69:2313-20

146. Tella M, Bravin MN, Thuriès L, Cazevieille P, Chevassus-Rosset C, et al. 2016. Increased zinc and copper availability in organic waste amended soil potentially involving distinct release mechanisms. Environ. Pollut. 212:299-306

147. Théry C, Ostrowski M, Segura E. 2009. Membrane vesicles as conveyors of immune responses. Nat. Rev. Immunol. 9:581-93

148. Tokmina-Lukaszewska M, Shi Z, Tripet B, McDermott TR, Copié V, et al. 2017. Metabolic response of Agrobacterium tumefaciens 5A to arsenite. Environ. Microbiol. 19:710-21

149. Traxler MF, Seyedsayamdost MR, Clardy J, Kolter R. 2012. Interspecies modulation of bacterial development through iron competition and siderophore piracy. Mol. Microbiol. $86: 628-44$

150. Vincent M, Duval R, Hartemann P, Engels-Deutsch M. 2018. Contact killing and antimicrobial properties of copper. J. Appl. Microbiol. 124:1032-46

151. Vorobev A, Jagadevan S, Baral BS, DiSpirito AA, Freemeier BC, et al. 2013. Detoxification of mercury by methanobactin from Methylosinus trichosporium OB3b. Appl. Environ. Microbiol. 79:5918

152. Waksman SA. 1947. What is an antibiotic or an antibiotic substance? Mycologia 39:565-69

153. Wichard T, Mishra B, Myneni SCB, Bellenger JP, Kraepiel AM. 2009. Storage and bioavailability of molybdenum in soils increased by organic matter complexation. Nat. Geosci. 2:625-29

154. Wright PM, Seiple IB, Myers AG. 2014. The evolving role of chemical synthesis in antibacterial drug discovery. Angew. Chem. Int. Edit. Engl. 53:8840-69 
155. Xin JY, Lin K, Wang Y, Xia CG. 2014. Methanobactin-mediated synthesis of gold nanoparticles supported over $\mathrm{Al}_{2} \mathrm{O}_{3}$ toward an efficient catalyst for glucose oxidation. Int. J. Mol. Sci. 15:21603-20

156. Xue XM, Ye J, Raber G, Rosen BP, Francesconi K, et al. 2019. Identification of steps in the pathway of arsenosugar biosynthesis. Environ. Sci. Technol. 53:634-41

157. Yan Y, Chen J, Galván AE, Garbinski LD, Zhu YG, et al. 2019. Reduction of organoarsenical herbicides and antimicrobial growth promoters by the legume symbiont Sinorhizobium meliloti. Environ. Sci. Technol. 53:13648-56

158. Yang HC, Rosen BP. 2016. New mechanisms of bacterial arsenic resistance. Biomed. J. 39:513

159. Yang Z, Peng H, Lu X, Liu Q, Huang R, et al. 2016. Arsenic metabolites, including $N$-acetyl4-hydroxy-M-arsanilic acid, in chicken litter from a roxarsone-feeding study involving 1600 chickens. Environ. Sci. Technol. 50:6737-43

160. Yoshinaga M, Cai Y, Rosen BP. 2011. Demethylation of methylarsonic acid by a microbial community. Environ. Microbiol. 13:1205-15

161. Yoshinaga M, Rosen BP. 2014. A C.As lyase for degradation of environmental organoarsenical herbicides and animal husbandry growth promoters. PNAS 111:7701-6

162. Young CA, Gordon LD, Fang Z, Holder RC, Reid SD. 2015. Copper tolerance and characterization of a copper-responsive operon, copYAZ, in an M1T1 clinical strain of Streptococcus pyogenes. J. Bacteriol. 197:2580-92

163. Zeph LR, Casida LE Jr. 1986. Gram-negative versus gram-positive (actinomycete) nonobligate bacterial predators of bacteria in soil. Appl. Environ. Microbiol. 52:819-23

164. Zhang X, Li B, Deng J, Qin B, Wells M, Tefsen B. 2020. Quantitative high-throughput approach to chalkophore screening in freshwaters. Sci. Total Environ. 735:139476

165. Zhu YG, Yoshinaga M, Zhao FJ, Rosen BP. 2014. Earth abides arsenic biotransformations. Annu. Rev. Earth Planet. Sci. 42:443-67 